\title{
STATISTIK SPASIAL KEPADATAN PENDUDUK TERHADAP KEJADIAN MALARIA DI KABUPATEN PURWOREJO DENGAN MENGGUNAKAN GIS
}

\author{
Sulistyawati \\ Fakultas Kesehatan Masyarakat Universitas Ahmad Dahlan Yogyakarta
}

\begin{abstract}
Background: Malaria was a problem in tropical countries including Indonesia. Purworejo regency lay on Central Java Province is a low malaria endemic area but in the end of year 2010 outbreak occurred. Malaria influenced by behavior, social economic condition include the population density.

Objective: To determine the relationship between malaria incidence and population density using GIS tool (spatial statistic).

Methods: This type of study is analytic research with GIS as tool analysis. Sample time frame is Nov 2010-March 2011 and the unit research for population density is village.

Results: Majority Village in Purworejo categorized in low population density. Malaria incidence at Nov 2010-March 2011 lay on the village with low population density. Result of Spatial statistic (using Geoda) spatially weighted regression shows that no relationship between malaria incidence and population density, $z$ value $=-0,800 ; p=0,432(p>0,05)$

Conclusion: There was no relationship between malaria incidence and population density (spatial statistic using Geoda).
\end{abstract}

Key words: malaria, GIS, population density

\section{PENDAHULUAN}

Malaria adalah penyakit yang menyerang manusia disebabkan oleh infeksi parasit yang disebut plasmodium, ditularkan melalui gigitan nyamuk terinfeksi. Parasit berkembang biak dalam tubuh manusia tepatnya di hati kemudian menginfeksi sel darah merah. ${ }^{1}$ Malaria merupakan penyakit menular yang dipengaruhi oleh lingkungan, disebabkan oleh parasit dan ditularkan oleh vektor. Malaria juga dipengaruhi oleh pola perilaku masyarakat di daerah tersebut beserta kondisi sosial ekonominya termasuk di dalamnya adalah kepadatan penduduk.

Kabupaten Purworejo merupakan kabupaten yang sudah sejak lama menjadi endemis malaria. Berdasarkan data dasar Dinas Kesehatan Kabupaten Purworejo ${ }^{2}$, kejadian malaria terendah terjadi pada tahun 2009 dibandingkan dengan empat tahun sebelumnya. Tahun 2009 Annual Parasite Insidence (API) Purworejo 0.44\%, 8 desa High Case Insidence $(\mathrm{HCl}), 20$ desa Moderate Case Incidence $(\mathrm{MCl})$ dan 7 desa Low Case Incidence (LCI). Tahun 2008 API 0.54\%, 15 desa HCI, 9 desa LCl, 23 desa MCl. Tahun $2007 \mathrm{API} 0.58 \%$, 14 desa $\mathrm{HCl}, 28$ desa $\mathrm{MCl}, 9$ desa LCl. Tahun 2006 API 0.55\%, 15 desa $\mathrm{HCl}, 31$ desa MCl, 20 desa LCl.

Sistem Informasi Geografi adalah seperangkat alat-alat untuk mengumpulkan, menyimpan, memanggil kembali, merubah dan menampilkan data spasial dari dunia nyata untuk suatu tujuan tertentu. Data geografis (keruangan) menampilkan dunia nyata yang mencakup: (a) posisi berdasarkan sistem koordinat, (b) atributnya atau kelengkapannya yang tidak berhubungan secara langsung dengan posisi (seperti warna, harga, lokasi penyebaran penyakit), (c) hubungan spasialnya antara satu dengan yang lainnya yang menjelaskan bagaimana mereka saling berhubungan atau biasa disebut dengan topologi dan penjelasan perangkat ruang dan spasial seperti keterkaitan yang tidak berpengaruh oleh distorsi atau kesalahan yang berkelanjutan. ${ }^{3}$ 
Prahasta $(2005)^{4}$ menyatakan bahwa kemampuan SIG dapat diketahui dari fungsi-fungsi analisis yang dilakukannya, yaitu:

a. Fungsi analisis spasial, terdiri dari

1. Klasifikasi (reclassify)

Fungsi ini mengklasifikasikan suatu data sehingga dihasilkan suatu data baru dengan kriteria tertentu.

2. Jaringan (network)

Fungsi ini menunjukkan feature titik, garis dan polygon sebagai suatu jaringan yang tak terpisahkan.

3. Tumpangsusun (Overlay)

Fungsi ini berguna untuk melakukan tumpang susun dua data atau lebih sehingga bisa menghasilkan informasi baru.

4. Buffering

Fungsi ini bertujuan memberikan zonasi terhadap suatu feature tententu.

5. Analisa tiga dimensi

Fungsi ini digunakan untuk representasi data spasial dalam ruang tiga dimensi, biasanya menggunakan fungsi interpolasi.

6. Pengolahan citra digital (image processing)

Fungsi ini biasa dilakukan terhadap format data yang berbentuk raster.

Geoda adalah jenis perangkat lunak open source (gratis atau non komersial) yang digunakan untuk eksplorasi analisis pada seperangkat data spasial. Geoda memberikan kelebihan mampu menggabungkan peta dengan statistik secara grafis. Geoda dibangun pertama kali sebagai prototipe pada tahun 2001 dan di rilis pertama kali pada tahun 2003. Penelitian ini bertujuan untuk mengetahui hubungan antara kepadatan penduduk dengan kejadian malaria di Kabupaten Purworejo.

\section{METODE PENELITIAN}

Jenis penelitian ini adalah penelitian survei analitik (observasional) dengan bantuan Sistem Informasi Geografi (SIG). Metode ini dipilih karena penelitian bermaksud melihat hubungannya kepadatan penduduk terhadap kejadian malaria dengan menggunakan teknologi Sistem Informasi Geografi. Penelitian ini dilakukan pada periode kasus November 2010-Maret 2011. Lokasi penelitian ini adalah seluruh kasus yang terjadi di Kabupaten Purworejo. Sampel (koordinat kasus) adalah semua kasus malaria yang dilaporkan di Dinas Kesehatan Kabupaten Purworejo dan terkonfirmasi positif secara mikroskopis sedangkan kepadatan penduduk diambil dari data penduduk Dinas Kesehatan Kabupaten Purworejo tahun 2010.

Instrumen yang digunakan dalam penelitian ini adalah peta spasial Kabupaten Purworejo dan Global Positioning System (GPS). Analisis data menggunakan perangkat lunak Geoda yaitu secara statistik spasial.

\section{HASIL DAN PEMBAHASAN}

Manusia merupakan subjek kejadian dari penyakit malaria, oleh sebab itu manusia harus memiliki pengetahuan penyakit malaria dan cara menghindarinya. Kepadatan penduduk per desa di Kabupaten Purworejo pada tahun 2011 yang diklasifikasikan menjadi 3 kelas yaitu tinggi, sedang dan rendah. Terlihat bahwa di Kabupaten Purworejo mayoritas desa-desa masuk dalam kelas kepadatan rendah, desa dengan klasifikasi kepadatan tinggi adalah Desa Kutoarjo, Kecamatan Ku- 
toarjo, dan Desa Bale Dono serta Desa Purworejo yang dua-duanya ada di Kecamatan Purworejo. Desa dengan klasifikasi kepadatan sedang terletak di Kecamatan Kemiri (Desa Bedono Kluwung), Kecamatan Pituruh (Desa Kalikotes, Sambeng, Karang Getas, Pekacangan, Keburusan), Kecamatan Butuh (Desa Andong, Lubang Kidul, Sidomulyo), Kecamatan Kutoarjo (Desa Wirun, Katerban, Semawung Daleman) dan Kecamatan Purworejo (Desa Mranti, Sindurjan, Pangenjuru Tengah, Tambak Rejo, Sendang Sari).

Gambar 1 menunjukkan peta kepadatan per-desa Kabupaten Purworejo yang ditumpangsusun (overlay) dengan kejadian malaria November 2010-Maret 2011, hasil tumpang susun memperlihatkan bahwa kejadian malaria pada bulan November 2010 terletak pada desa dengan kelas kepadatan rendah.

Hasil tumpang susun dengan kejadian malaria pada bulan Desember 2010. Hasil tumpang susun menunjukkan bahwa dengan kuantitas yang meningkat lokasi kejadian malaria masih di desa dengan kelas kepadatan rendah. Hasil tumpang susun peta kepadatan penduduk per desa Kabupaten Purworejo dengan kejadian malaria pada bulan Januari 2011, peta itu menunjukkan bahwa kuantitas kejadian malaria meningkat dengan lokasi desa masih dalam klasifikasi kepadatan rendah selanjutnya pada bulan Februari 2011 menunjukkan bahwa secara kuantitas kejadian malaria menurun drastis, namun seperti pada bulan-bulan sebelumnya kejadian malaria terletak pada desa dengan kelas kepadatan rendah. Bulan terakhir penelitian menunjukkan bahwa kejadian malaria sudah menurun, namun kejadian malaria masih terletak di desa dengan kelas kepadatan rendah.

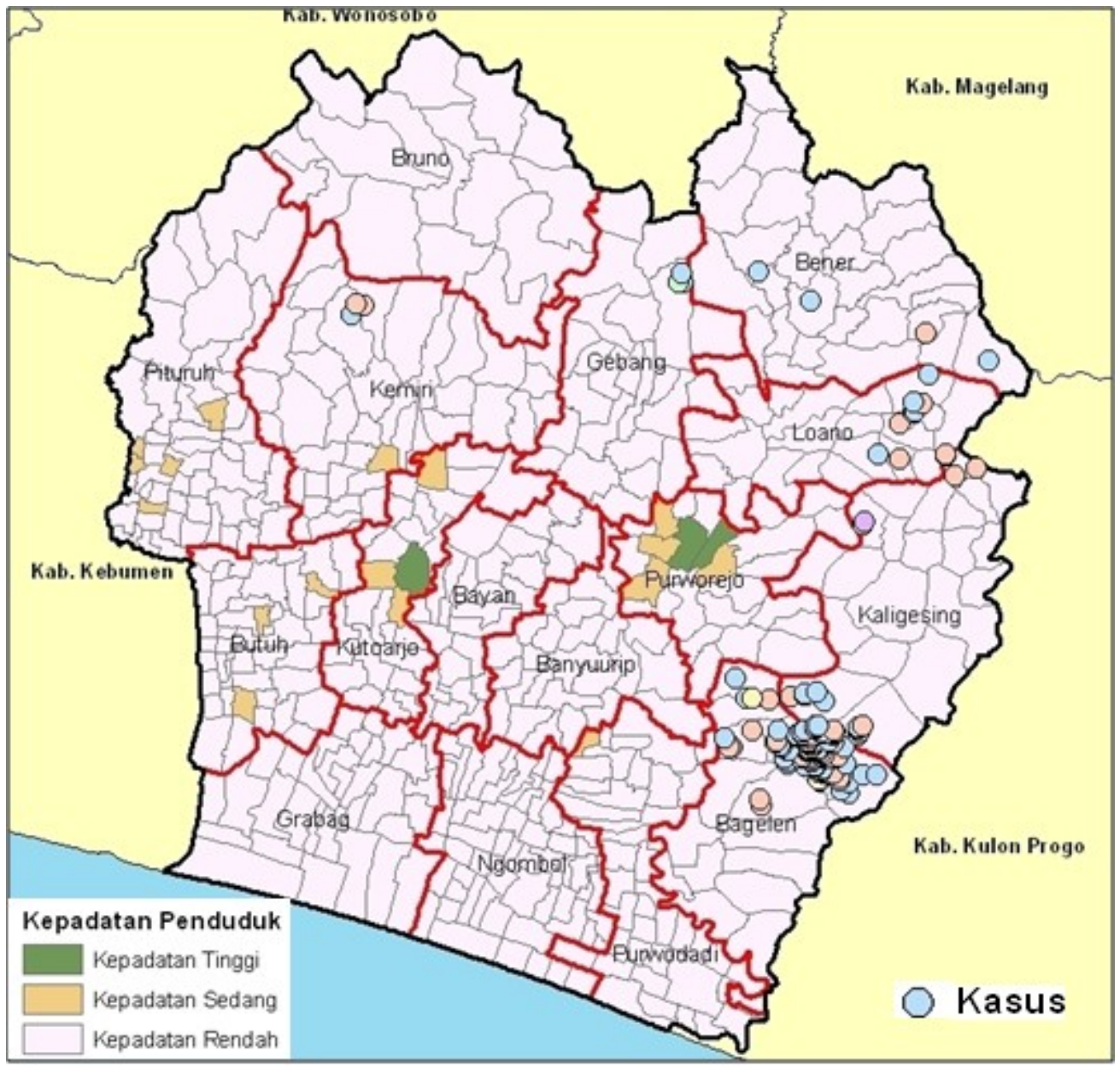

Gambar 1. Overlay Kejadian Malaria (Nov 2010-Maret 2011) dan Kepadatan Per Desa Kab Purworejo Tahun 2010 
Nyamuk Anopheles penyebab malaria merupakan tipe yang senang dengan manusia. Di Kabupaten Purworejo kejadian malaria selama masa studi (November 2010-Maret 2011) terdistribusi di kecamatan yang memiliki kepadatan rendah. Hasil uji statistik dengan menggunakan Geoda diperoleh dengan $z$ value $=-0.800$ dengan $p=0,423(P>0,05)$ yang artinya menunjukkan bahwa tidak ada hubungan bermakna antara kepadatan penduduk dan kejadian kejadian malaria di Kabupaten Purworejo. Hal ini sesuai dengan penelitian Gunawan, NA (2000) ${ }^{5}$ yang menyebutkan bahwa tidak ada hubungan antara kepadatan penduduk dan kejadian malaria dan pola pergerakan kejadian malaria dari daerah yang berpenduduk jarang ke penduduk yang padat.

Penelitian ini diharapkan dapat menjadi bahan evaluasi dan masukan untuk meningkatkan program pengendalian malaria di Kabupaten Purworejo. Survei semacam ini secara menyeluruh dapat mengukur cakupan intervensi seperti kelambu, penyemprotan dan mengetahui ketimpangan (gap) yang harus diisi di daerah penelitian.

\section{KESIMPULAN DAN SARAN}

A. Tidak terdapat hubungan bermakna antara kepadatan penduduk dengan kejadian malaria di Kabupaten Purworejo (spasial stastistic).

B. Bagi peneliti yang akan melakukan penelitian lanjutan agar bisa melibatkan variabel terkait yang lain sehingga mampu memberikan masukan kepada Dinas Kesehatan setempat secara lebih spesifik.

\section{DAFTAR PUSTAKA}

1. WHO, WHO: Malaria: http://www.who.int/topics/malaria/en/, diakses pada tanggal 16 Juni 2011, Yogyakarta. 2011

2. Dinas Kesehatan Kabupaten Purworejo, Laporan Bulanan Penemuan dan Pengobatan Malaria 2010-2011, Purworejo. 2011

3. Burrough Pengertian Sistem Informasi Geografi: http:// www.geografi.web.id/2008/12/pengertian-sistem-informasi-geografi.html, diakses pada tanggal 15 April 2010 -10 Desember 2010, Yogyakarta. 1986

4. Prahasta, E., Konsep-Konsep Dasar Sistem Informasi Geografis, Informatika, Bandung. 2005

5. Gunawan, N.A., Analisa Spasial Penyakit Malaria di Kabupaten Banjarnegara Provinsi Jawa Tengah 1996-2000, Thesis, Universitas Indonesia. 2000 